\title{
The Response of Haricot Bean (Phaseolus Vulgaris L) Varieties to Phosphorus Levels on Nitosols at Wolaita Zone, Ethiopia
}

\author{
Mesfin Kassa, Belay Yebo Abera Habte \\ Wolaita Sodo University, College of Agriculture, P.O.BOX 138, Wolaita Sodo, Ethiopia \\ E-mail of the corresponding author: mesfine2004@gmail.com
}

\begin{abstract}
A field experiment was conducted at two locations (Bolosso Sore and Damot Sore) in Wolaita Zone of Southern Nations Nationalities and People's Regional State to evaluate the response of two varieties of haricot bean (phaseolus vulgaris $L$.) to phosphorus fertilizer rates on acidic soils. Combinations of four levels of $\mathrm{P}(0,10,20$ and $30 \mathrm{~kg} \mathrm{ha}^{-1}$ ) were used on two varieties. The treatments were arranged in factorial RCBD with three replications. Analysis resulted of soil samples showed that Available P, Organic carbon, Total Nitrogen \& Soil $\mathrm{pH}$ values were very low. Application of lime with $\mathrm{P}$ resulted significant changes on these chemical properties of the soils in the two locations. The maximum values of these parameters recorded at $30 \mathrm{~kg} \mathrm{Pha}^{-1}$. Growth parameters yield and yield components were significantly increased with increasing rates of $\mathrm{P}$ at the two locations. Maximum grain yields (1488.40 and $1523.7 \mathrm{kgha}^{-1}$ for Hawse Dume at Gunno and Dollar, respectively and 1242.12 and $1352.01 \mathrm{kgha}^{-1}$ for Omo-95 at Gunn and Dollar, respectively) recorded at rates of $30 \mathrm{kgPha}^{-1}$ in the both locations. From the result of this study it could be conclude that improve soil pH, Available P and performance of haricot bean varieties but till now there is some gap on correcting $\mathrm{P}$ application of grain yield of the varieties. So application of $\mathrm{P}$ could be increased the production of the crops.
\end{abstract}

Keywords: Hawse Dume, Omo-95, soil acidity and yield

\section{Introduction}

Haricot bean (Phaseolus vulgaris $L$ ) is annual pulse crop with considerable variation in habit, vegetation characters, flower color and the size, shape of pods and seeds (Onwueme and Sinha, 1999). It was probably first cultivated with maize, and it seems likely that the two crops evolved together in a cereal-Legume farming system in much the same way as cowpeas and sorghum in West Africa. It is widely cultivated thought out different parts of Ethiopia. It is produced in four major agro ecological zones, including the central, eastern, southern and western zones. Haricot bean is mainly used as source of food and cash. It is exported to earn foreign exchange and is also one of the cash crops locally used by farmers as source of food. Additionally farmers also grow the bean to use as forage for livestock and mulching. Haricot bean cultivation can be carried out without large input and intensive practices and this makes it suitable for poor farmers where the need in food supply is important. It can be used in intercropping system with maize and between young trees until canopy closure.

Yield of legumes in farmers field is usually less than $0.65 \mathrm{t} / \mathrm{ha}$ against the potential yield of $1.2 \mathrm{t} / \mathrm{ha}$ suggesting a large yield gap (CACC, 2002). Low yield potential of legumes has made them less competitive with cereals and other high value crops. The yield of haricot bean increase with $\mathrm{p}$ application and its nodulation and fixation of $\mathrm{N}$ can be also improved with the application of $\mathrm{P}$ (Gemetchu, 1990). The average national productivity of haricot bean is $0.72 \mathrm{t} / \mathrm{ha}(\mathrm{CACC}, 2002)$ and its regional productivity is $0.81 \mathrm{t} / \mathrm{ha}$.

The major bean producing area in the southern zone includes Gamo Goffa, Sidamo and Wolaita (Gemechu, 1990). Haricot bean is also one of the most communal cultivated pulse crops in the Wolaita area where its yield is lower than regional and national yields. The low yield is contributed from acidity of soils which reduce availability of $\mathrm{P}$ and basic cations as $\mathrm{Ca}$ and $\mathrm{Mg}$ and also affect activities of soil microorganisms (Havlin et al., 1999). Haricot bean is mainly used as sources of food and cash. It is exported to earn foreign exchange and is also one of the cash crops locally used by farmers (Mitiku, 1990). As source of food, it is extensively consumed in traditional dishes, and being part of the diet of the farming households, it serves as a source of protein to supplement the protein deficient main dishes like maize and enset in the southern parts of our country especially in Wolaita and Sidamo areas (Tenaw and Yeshi, 1990).

Besides, the farmers also grow the bean to use the straw as forage for livestock, source of fuel, mulching, bedding, and covering material for houses of poor farmers. Despite all these advantages, little effort was made to improve its productivity and the yield is comparatively low because of depletion of nutrients as a result of erosion and crop mining, lack of optimum fertilizer rate, etc. One of the solutions to alleviate the problem could be applying $\mathrm{P}$ fertilizers from external sources based on recommended rate for the crop. In order to make sitespecific recommendation of $\mathrm{P}$ for haricot bean production, characterization of the soil at the experimental site, and nutrient rate experiment are needed. Therefore, this study was initiated with the objectives to characterize 
the soil of the experimental site, and evaluate the response of haricot bean to increasing levels of $\mathrm{P}$ application. Even though application of lime with $\mathrm{P}$ brings positive effect on soil conditions and crop performance, in Wolaita area where the problem of soil acidity is very chronic, little or no work is done to verify whether there is response of crops to $\mathrm{P}$ application rates with liming or not. Furthermore, to use fertilizer with lime as source of nutrients, there should be site specific recommendation to maintain optimum level of nutrients. Therefore, this study was initiated with the following objectives.

$>$ To evaluate the response of haricot bean varieties to different rates of $\mathrm{P}$ fertilizer

$>$ To compare the performance of haricot bean varieties

$>$ To observe the interaction effect of $\mathrm{P}$ with haricot bean varieties

\section{MATERIALS AND METHODS}

\subsection{Description of the Study Site}

The researches were conducted during the 2012-2013 rainy season at two locations, which is located in Wolaita Zone, Southern Nations Nationalities and People's Regional State (SNNPRS). The first one was at Boloso Sore district, which is located at $307 \mathrm{~km}$ south of Addis Ababa and $5 \mathrm{~km}$ from Areka town, at $7^{\circ} 04.196 \mathrm{~N}$ and $37^{\circ} 41.330^{\prime} \mathrm{E}$ and altitude of 1790 meters above sea level.

The second location was Damot sore district, which is located $330 \mathrm{~km}$ south of Addis Ababa and $2 \mathrm{~km}$ from Gununo town, at $6^{\circ} 56^{\prime} \mathrm{N}$ and $37^{\circ} .39^{\prime} \mathrm{E}$ and altitude of 1790 meters above sea level. There was no meteorological station in the study area, which is found $3 \mathrm{~km}$ far from Boloso Sore district. The two districts are with mean annual rainfalls of $1460 \mathrm{~mm}$ with a bimodal pattern, which extends from March to September. The peak rainy months are April, July, August and September. The mean minimum and maximum temperatures are $15^{\circ} \mathrm{C}$ and $26^{\circ} \mathrm{C}$, respectively. The representative date was collected from Areka Agricultural Research Center.

\subsection{Treatments and Experimental Design}

Hawassa Dume and Omo-95 haricot bean varieties were used for test crop to compare its response to phosphorus fertilizer rates. The levels used were $0,10,20$ and $30 \mathrm{~kg} \mathrm{P} \mathrm{ha}^{-1}$. The treatments were arranged in factorial RCBD with three replication. Five rows each have fifteen plants were used on plot having size of $2.0 \mathrm{~m}$ by $1.5 \mathrm{~m}$. Spacing of 10, 40, 50 and $100 \mathrm{~cm}$ were used between plants, rows, plots and blocks, respectively. Urea at rate of $50 \mathrm{~kg} \mathrm{ha}^{-1}$ and all doses of $\mathrm{P}$ were applied at planting time. TSP for $\mathrm{P}$ and urea for $\mathrm{N}$ were used as source of fertilizer.

\subsection{Agronomic Data Collection}

Flowering and maturity dates (when $50 \%$ of the plants were at respective phonological stage), number of branches per plant, plant height, number of pods per plant, number of leaf per plants ,pod length, number of seeds per pod and seed yield were recorded. Three central rows were harvested for determination of grain yield and total biomass.

\subsection{Soil Sampling and Analysis}

The soil samples were air-dried and ground to pass 2 and $0.5 \mathrm{~mm}$ (for total $\mathrm{N}$ ) sieves. All samples were analyzed following standard laboratory procedures as outlined by (Sahlemedhin and Taye ,2000). Organic carbon and total $\mathrm{N}$ contents of the soil were determined following the wet combustion method of Walkley and Black, and wet digestion procedure of Kjeldahl method, respectively. Available P was extracted by Olsen method. Soil texture was analyzed by Bouyoucos hydrometer method. The $\mathrm{pH}\left(\mathrm{H}_{2} \mathrm{O}\right)$ of the soils was measured in water using $\mathrm{pH}$ meter with glass-calomel combination electrode.

\subsection{Statistical Analysis}

The data obtained from soil and crop, were statistically analyzed using the PROC ANOVA function of SAS and means were compared using LSD at a probability level of $5 \%$.

\section{RESULTS AND DISCUSSION}

\subsection{Physicochemical Properties of Soil}

Soil analysis of the two locations before sowing in two years (Table 1) showed that $\mathrm{pH}$ values (5.0 and 5.6) found in the range of strong acid based on Herrera (2005) classification. Whereas the P application were resulted in a significant increase in soil $\mathrm{pH}$ compared to two verities, the application $\mathrm{P} 30 \mathrm{~kg} / \mathrm{ha}$ it's led to slight decrease soil acidity in both year1\&2, but this was not significant (Table 2). Lime combined with P fertilizer gave the mean highest value of soil $\mathrm{pH}$ (6.12) at Dolla site while P fertilizer applied had the least (5.2) at Gununo site . This result clearly indicated that the area is seriously affected by soil acidity, which is not satisfactory for growth of most crops (Havlin et al., 1999).

The range of available phosphorous contents of the two locations $\left(0.6\right.$ and $\left.1 \mathrm{mg} \mathrm{kg}^{-1}\right)$ before sowing was very low (Table 1) this range was very low based on (Herrera, 2005). This low concentration of available $\mathrm{P}$ may be related to acidity of the soil which bring fixation of $\mathrm{P}$ (Havlin et al., 1999). The highest concentration of Av.P (5.2-6.1 mg/kg) was recorded under year 2 in Gununo and Dolla site respectively, whereas the lowest Av.P was 
found at year 1 at two locations. The differences in Av.P concentration in soil might be resulted from changes in biological and geochemical processes at different activities after human disturbances.

Application of $\mathrm{P}$ might contributed in releasing some amount of fixed $\mathrm{P}$ to be available for the crop. This also indicates that deficiency of $\mathrm{P}$ cannot be replaced other atoms. As a result in acidic soils which are deficient in Av.P, OC and TN are important to apply P together with other nutrients to increase crop production. The same result was obtained in the year 1 and 2 of the OC and TN in experiment site. Statistically there was no significant difference on TN and OC of soils in both locations. On the other hand, application of $\mathrm{P}$ resulted significant variation on soil $\mathrm{pH}$ and available $\mathrm{P}$ in the two locations of year1 \& 2. First year and second years $\mathrm{P}$ application had affect haricot bean production. This is in agreement with Anetor and Ezekiel (2007) who indicated that lime increased $\mathrm{pH}$ and available $\mathrm{P}$ in Nigeria. However, potassium and exchangeable acidity were decreased with increasing application. Textural analysis showed that the same textural class according to the present study soil textural class was sandy loam in both locations and there is no significantly difference between year $1 \& 2$. The lack of soil textural class difference between year $1 \& 2$ at both location its might be attributed to the similarity in parent material from which the soils originate.

Table 12. Physiochemical properties of the soil before sowing at Dolla and Gununo,2012-13

\begin{tabular}{|c|c|c|c|c|c|c|c|c|c|}
\hline & & $1 \mathrm{pH}$ & Av. p (ms & & TN \% & $\mathrm{OC} \%$ & & tural class & \\
\hline location & yr1 & yr 2 & $\mathrm{yr} 1$ & yr 2 & $\mathrm{yr} 1$ & yr 2 & $\mathrm{yr} 1$ & yr 2 & \multirow[b]{2}{*}{ Sandy loam } \\
\hline Dolla & 5.3 & 5.6 & 1.00 & 6.12 & 0.15 & 1.75 & 0.15 & 0.31 & \\
\hline Gununo & 5.0 & 5.4 & 0.60 & 5.22 & 0.12 & 0.18 & 0.10 & 1.70 & Sandy loam \\
\hline
\end{tabular}

Table 2. Mean value phosphorus on soil chemical properties at Gununo and Dolla, 2 012-2013

\begin{tabular}{|c|c|c|c|c|c|c|c|c|c|}
\hline \multicolumn{10}{|c|}{ Treatment } \\
\hline & & \multicolumn{4}{|c|}{ Gununo } & \multicolumn{4}{|c|}{ Dolla } \\
\hline & $\mathrm{p}$ & Soil pH & Av. $p$ & \multicolumn{2}{|c|}{$\mathrm{OC}$} & Soil $\mathrm{pH}$ & Av. p & \multicolumn{2}{|c|}{$\mathrm{OC}$} \\
\hline & 0 & 5.2 & 0.8 & 0.3 & 0.8 & 5.5 & $0.6 \mathrm{c}$ & 0.10 & 0.4 \\
\hline & 10 & 5.2 & 0.9 & 0.3 & 0.8 & 5.6 & $1.1 \mathrm{~b}$ & 0.22 & 0.4 \\
\hline & 20 & 5.3 & 0.9 & 0.3 & 0.8 & 5.6 & $1.7 \mathrm{a}$ & 0.23 & 0.4 \\
\hline & 30 & 5.3 & 0.9 & 0.3 & 0.8 & 5.7 & $1.7 \mathrm{a}$ & 0.36 & 0.4 \\
\hline \multicolumn{2}{|l|}{ LSD $_{5 \%}$} & 0.33 & 1.3 & \multicolumn{2}{|c|}{0.03} & \multicolumn{2}{|c|}{0.03} & \multicolumn{2}{|c|}{0.33} \\
\hline $\mathrm{CV}$ & \multicolumn{2}{|c|}{4.4} & 18 & \multicolumn{2}{|c|}{39} & 65 & 18 & \multicolumn{2}{|c|}{39} \\
\hline
\end{tabular}

These dates were year $1 \& 2$ content of the soil exhibited an increasing trend with increasing rates of liming material application. The changes of soil $\mathrm{pH}$ and Av.P of soil may be attributed to the neutralizing of acid soil due to application of lime and also application of $\mathrm{P}$ fertilizer at increasing rates (Tisdale et al., 1993).

\section{2 .Effect of phosphorus on growth performance of haricot bean verities}

Application of $\mathrm{P}$ at different rates resulted significant variation on growth parameter of plant in the two locations (Table 3). Growth parameters such as plant height, leaf and branches number were increased significantly as the rates of $\mathrm{P}$ increased. Maximum values of plant heights, leaf and branches numbers were recorded at application rates of $30 \mathrm{kgPha}^{-1}$ in the two locations Hawassa Duma had better performance than Omo-95. In line with this result Kisinyo et al. (2005) indicated that growth of plant increased in acid soil as application of $P$ increased with and without lime. This positive growth response of haricot bean for application of $\mathrm{P}$ in acidic soil may be a related with better availability of $\mathrm{P}$ as the rates of $\mathrm{P}$ application increased. Furthermore, plant did have better performance, which may come from the effect of $\mathrm{P}$ on soil acidity and in turn improve the availability of $\mathrm{P}$ for crops. Similar result was also reported by (Singh and Tripathib, 1994). 
Table 4. Mean value phosphorus on growth performance of haricot bean varieties at Gununo and Dolla in 2011/12- 2013/14

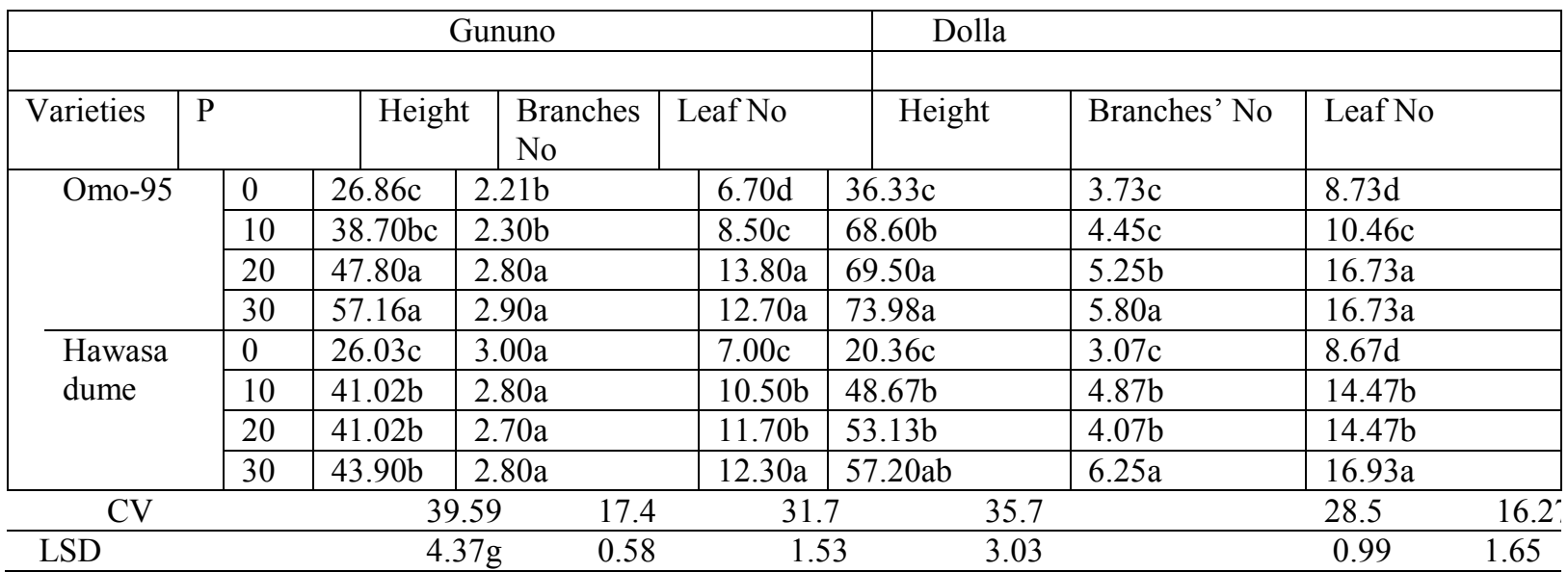

Values followed by the same letter (s) within a column are not significantly different at $\mathrm{P} \leq 0.05$

NS- not significant

\subsection{Effect of phosphorous on yield and yield component of haricot bean varieties}

\subsubsection{Pods number and length}

Analysis of variance showed that there was significant effect of phosphorus rates on number and length of pods for both varieties in two locations. Maximum number and length of pods were recorded at rate of $30 \mathrm{~kg} \mathrm{Pha}^{-1}$ with verity of Hawassa dume while Omo-95 had lower performance (Table 4). Such increment of pods number and length with increasing rate of $\mathrm{P}$ may be attributed to the better availability of $\mathrm{P}$ for plants as the rate of external $\mathrm{P}$ application increase which in turn observed on better plant performance. In agreement with this result Girma Abebe (2009) also stated that pod numbers of haricot bean increased with the increasing of P rates. Effect of $\mathrm{P}$ and haricot bean verities were significant whereas $\mathrm{P}$ fertilizer had interaction with haricot bean varieties were significantly $(\mathrm{P}<0.05)$ affected pod number of the hawassa dume verity. Highest number of pods per plant (14.0) was produced when the crop was grown in $30 \mathrm{~kg}$ Pha'.

Finding is also in line with reports of Malik et al. (2006) who indicated more pod number per plant of soybean

\subsubsection{Seeds number and seed yields}

There was significant variation on seed number per pod and seed yield ha ${ }^{-1}$ due to application of phosphorous for the two varieties. Maximum number of seeds per pod and seed yield $\mathrm{ha}^{-1}$ at the two locations were recorded at 30 $\mathrm{kgPha}^{-1}$ for both varieties and seeds number and seed yield were increased with increasing rates of P. So this result indicated that $\mathrm{P}$ improves availability of $\mathrm{P}$ for crops and also external $\mathrm{P}$ application improved crop yield performance. The result may be attributed to the fact that applying phosphorus fertilizer increases crop growth and yield on soils which are naturally low in P and in soils that have been depleted (Mullins, 2001).

Table 5. Mean value of phosphorus on yield and yield components performance of haricot bean varieties at Gununo and Dolla in 2012-2013/14

\begin{tabular}{|c|c|c|c|c|c|c|c|c|c|}
\hline \multicolumn{7}{|c|}{ Gununo } & \multicolumn{3}{|l|}{ Dolla } \\
\hline Varity & $\mathrm{P}$ & $\begin{array}{l}\text { Pod } \\
\text { No }\end{array}$ & $\begin{array}{l}\text { Seed } \\
\text { No }\end{array}$ & $\begin{array}{l}\text { Pod } \\
\text { Length }\end{array}$ & $\begin{array}{l}\text { Seed } \\
\text { Yield }\end{array}$ & $\begin{array}{l}\text { Pod } \\
\text { No }\end{array}$ & $\begin{array}{l}\text { Seed } \\
\text { No }\end{array}$ & $\begin{array}{l}\text { Pod. } \\
\text { Length }\end{array}$ & \begin{tabular}{|c} 
Seed \\
yield
\end{tabular} \\
\hline \multirow[t]{4}{*}{ Omo-95 } & 0 & $7 . \overline{40}$ & $5.2^{\mathrm{bc}}$ & $7.4 \mathrm{c}$ & $671.27 b$ & $7.9 \mathrm{~cd}$ & $5.9 a$ & 6.8 & $682.28 \mathrm{c}$ \\
\hline & 10 & 6.80 & $4.9 \mathrm{c}$ & $8.3 b$ & $768.61 \mathrm{~b}$ & $6.6 \mathrm{~d}$ & $4.8 \mathrm{c}$ & 8.1 & $790.28 b c$ \\
\hline & 20 & 10.10 & $5.7 \mathrm{a}$ & $8.8 \mathrm{a}$ & $819.29 b$ & $10.1 \mathrm{~b}$ & $5.8 \mathrm{a}$ & 9.1 & $872.07 b c$ \\
\hline & 30 & 10.9 & $5.9 \mathrm{a}$ & $8.9 \mathrm{a}$ & $1046.11 \mathrm{a}$ & $10.8 \mathrm{~b}$ & $6.0 \mathrm{a}$ & 9.2 & $1156.07 \mathrm{a}$ \\
\hline \multirow{4}{*}{$\begin{array}{l}\text { Hawassa } \\
\text { dume }\end{array}$} & 0 & 5.2 & $4.5 \mathrm{c}$ & $7.4 \mathrm{c}$ & $715.44 b$ & $4.9 \mathrm{e}$ & $4.7 \mathrm{c}$ & 7.7 & $795.43 b c$ \\
\hline & 10 & 8.8 & $5.4 \mathrm{~b}$ & $8.8 \mathrm{a}$ & $926.14 \mathrm{a}$ & $8.4 \mathrm{c}$ & $5.3 \mathrm{~b}$ & 9.0 & $972.61 \mathrm{ab}$ \\
\hline & 20 & 10.1 & $5.1 b c$ & $8.8 \mathrm{a}$ & $990.50 \mathrm{a}$ & $8.3 \mathrm{c}$ & $5.1 b c$ & 8.9 & $1013.37 \mathrm{ab}$ \\
\hline & 30 & 12.9 & $5.7 \mathrm{a}$ & $8.9 \mathrm{a}$ & $1089.12 \mathrm{a}$ & $12.9 \mathrm{a}$ & $6.1 \mathrm{a}$ & 9.3 & $1110.46 a$ \\
\hline $\mathrm{CV}$ & & 27.7 & 17.14 & 9.5 & 34.27 & 22.7 & 11.9 & 0.79 & 46 \\
\hline LSD & & 1.43 & 0.44 & 0.57 & 201 & 1.65 & 0.65 & 3.11 & 200 \\
\hline
\end{tabular}

Values followed by the same letter (s) within a column are not significantly different at $\mathrm{P} \leq 0.05$ 


\section{SUMMARY AND CONCLUSION}

A field experiments were conducted at the two locations on acidic soil to study the effect of phosphorus application on haricot bean verities at Dolla and Gununo in Wolaita Zone, Southern Ethiopia. The research work was initiated to evaluate the response of haricot bean varieties to different rates of $\mathrm{P}$ fertilizer on acid soils. The experiment was laid out in factorial randomized complete block design with three replications. Hawasa dume and Omo-95 were treated by combination of four rates of $\mathrm{P}\left(0,10,20\right.$ and $\left.30 \mathrm{kgPha}^{-1}\right)$

Soil samples were collected from two locations before sowing and at maturity for analysis of some selected physical and chemical properties of soil (texture, Soil pH, Av.P, OC, and TN). Laboratory analysis result of the soil samples taken before sowing and at harvest revealed that all the soil parameters were at lower rates even though the soil was treated by different rates of P. Available Phosphorus was showed increasing tendency with increasing soil $\mathrm{pH}$ on both location with two seasons. The overall result of chemical properties in this study, demonstrated that most soil parameters were significantly different with lime application at two areas.

There was a significant increase on growth parameters of the two varieties as rates of $\mathrm{P}$ fertilizer increased both location at Dolla and Gununo. Maximum values of plant height, leaves and branches number were recorded at application rates of $30 \mathrm{kgPha}^{-1}$ at both location in year1\&2. Similarly, the highest grain yield and yield components were obtained at $30 \mathrm{~kg} \mathrm{P} \mathrm{ha}^{-1}$ on both varieties at two locations. In general in the study area; strong acidity and low values of some chemical properties of the soil. The application of $P$ fertilizer increased yields of haricot bean; however, the grain yields were low compared with crop potential. This indicates that a two season treatment of P can correct problem of soil acidity. So it is recommended that correcting of soil acidity should be done for growth seasons until soil comes to neutral conditions and increased crop production.

\section{ACKNOWLEDGEMENT}

We are hugely indebted to Wolaita Sodo University for the research work grant (Grant number WSU/2004/01) and following to do our research concern. Finally, we are indebted to the Department of Plant Science of Wolaita Sodo University for their contribution in the process of developing the research proposal and provision of various services

\section{References}

Anetor. M and Ezekiel A (2007), "Lime effectiveness of some fertilizers in a tropical acid alfisol", University of Ibadan, Ibadan, Nigeria

Bekere, W., Kebede T. and Dawud J. (2013). Growth and Nodulation Response of Soybean (Glycin maxL.) to Lime, Bradyrhizobium Japonicumand Nitrogen Fertilizer in Acid Soil at Melko, South Western Ethiopia. Int. J. Soil sci.8 (1): 25-31

CACC (Central Agricultural Census Commission). 2002. Report on the Preliminary Results of Area, Production and Yield of Temporary Crops (Meher Season, Private Peasant Holdings) Part I. Addis Ababa, Ethiopia. $200 \mathrm{p}$

Cassman, K.G., A.S. Whitney and K.R. Stockinger, (1980). Root growth and dry matter distribution of soybean as affected by phosphorus stress, nodulation and nitrogen source. Crop Sci., 20: 239-244.

Chalk, P.M., B.J.R. Alves, R.M. Boddey and S. Urquiaga (2010). Integrated effects of abiotic stresses on inoculants performance, legume growth and symbioticdependence estimated by $15 \mathrm{~N}$ dilution. Plant Soil, 328: 1-16

Gemechu Gedno 1990. Haricot bean (Phaseous Vulgaris L.) Agronomic Research at Bako. Research on Haricot bean in Ethiopia: an Assessment of Status, Progress, Priorites and Strategies. Proceeding of a National Workshop held in AddisAbaba,1-3October 1990.114p.

Havlin, J.L., J.D. Beaton, S.L. Tsidale, and L. Nelson, 1999. Fertility and Fertilizers. An Introduction to Nutrient Management $\left(6^{\text {th }}\right.$ ed). Prentice Hall. Inc. Upper Saddle River, New Jersey.

Herrera, E., 2005. Soil Test Interpretation. Guide A - 122. College of Agriculture and Home Economics. New Mexico State University phosphorus deficiency. Oxford Journal of Sciences, 94(3):323-332.

Kisinyo, C.o. Othieno, j.r. Okalebo, m.j. Kipsat, a.k. Serem \& D.o. Obiero. Effects of lime and phosphorus application on early growth of Leucaena in acid soils moi University, School of Agriculture and Biotechnology, Eldoret, Kenya

Malik, M. A., M. A. Cheema, H. Z. Khan and M. W. Ashfaq (2006). Growth and yield response of soybean (Glycine max L.)to seed inoculation and varying phosphorus levels. Journal of Agricultural Research 44(1):47-53

Mullins G., 2001. Phosphorus, agriculture \& the environment. Virginia Cooperative Extension, Virginia state university. No: 424-029.

Onwueme, I.C. and T.D. Sinha, 1999. Field Crop Production in Tropical Africa. CTA. Wageningen, 
Netherlands.

Oster, J.D., 1982. Gypsum usage in irrigated Agriculture. A review. Fert. Res. 3:73-89.

Ponette, Q., Belkacem, S. \& Nys, C., 1996. Ion dynamics in acid forest soil as affected by addition of Ca fertilizers. Geoderma 71(1996) 53-76.

Sahlemedhin Sertsu and Taye Bekele. 2000. Procedures for Soil and Plant Analysis. National Soil Research Center, EARO, Technical Paper No. 74, Addis Ababa, Ethiopia

Singh, D.N., and Tripathi, P., 1994, Effect of NPK fertilizers and spacing on growth and yield of French bean. Veg. Sci., 21:7-11.

Tisdal, S. L., W.L. Nelson, J.D. Beaton and D.L. Havlin, 1995. Soil Fertility and Fertilizer (5 ${ }^{\text {th }}$ ed.). Macmillan Publishing Company. Pp634 
The IISTE is a pioneer in the Open-Access hosting service and academic event management. The aim of the firm is Accelerating Global Knowledge Sharing.

More information about the firm can be found on the homepage:

http://www.iiste.org

\section{CALL FOR JOURNAL PAPERS}

There are more than 30 peer-reviewed academic journals hosted under the hosting platform.

Prospective authors of journals can find the submission instruction on the following page: http://www.iiste.org/journals/ All the journals articles are available online to the readers all over the world without financial, legal, or technical barriers other than those inseparable from gaining access to the internet itself. Paper version of the journals is also available upon request of readers and authors.

\section{MORE RESOURCES}

Book publication information: http://www.iiste.org/book/

\section{IISTE Knowledge Sharing Partners}

EBSCO, Index Copernicus, Ulrich's Periodicals Directory, JournalTOCS, PKP Open Archives Harvester, Bielefeld Academic Search Engine, Elektronische Zeitschriftenbibliothek EZB, Open J-Gate, OCLC WorldCat, Universe Digtial Library, NewJour, Google Scholar

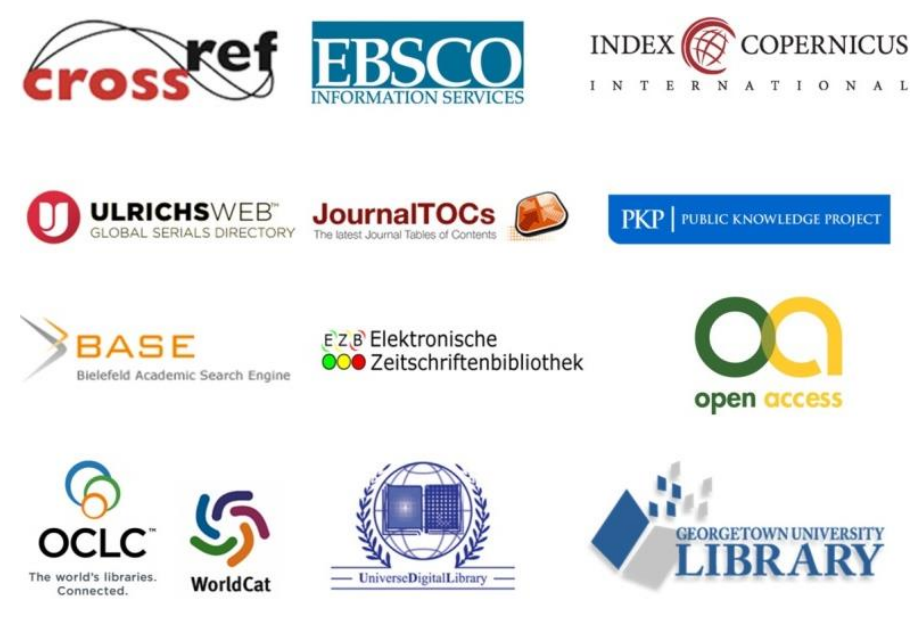

